\title{
Upaya Penerapan Supervisi Pendidikan di Sekolah untuk Meningkatkan Kompetensi Keprofesionalan Guru
}

\author{
Diana Novita (17078063) \\ Prodi Pendidikan Tata Rias dan Kecantikan \\ Universitas Negeri Padang \\ Indonesia \\ Email : diananovita0211@gmail.com
}

\begin{abstract}
ABSTRAK
Artikel ini ditulis untuk memenuhi tugas akhir administrasi dan supervisi pendidikan. Metode yang digunakan dalam penulisan artikel ini adalah metode studi literatur, yaitu dengan mengumpulkan data dari berbagai sumber literatur seperti internet. Dalam artikel tersebut dijelaskan bahwa kurikulum adalah seperangkat rencana dan peraturan mengenai isi dan materi pelajaran serta metode yang digunakan sebagai pedoman dalam pelaksanaan proses pembelajaran. Proses administrasi supervisi mencakup bidang perencanaan, pengembangan, implementasi, evaluasi, dan peningkatan. Berdasarkan hal ini kita dapat mengetahui bahwa peran supervisi dalam pendidikan formal di sekolah sangat penting dan memiliki pengaruh besar dalam menentukan pencapaian tujuan pendidikan.
\end{abstract}

Keywords : supervise, manajerial supervise, supervise pendidikan

\section{A. PENDAHULUAN}

Perkembangan ilmu pengetahuan, teknologi, dan sosial ekonomi masyarakat dapat lebih memperluas variasi pendekatan peningkatan kapasitas guru. Secara umum dikenal, supervisi dilakukan oleh supervisor dengan melakukan kunjungan kelas. Supervisor memeriksa persiapan guru mengajar dan mengomentari persiapan mengajar yang dibuat oleh guru. Selanjut mengamati mengajar dan mencatat segala sesuatu berkenaan dengan pelaksanaan pembelajaran yang dilakukan oleh guru. Hasil pengamatan tersebut dibicarakan dengan guru; supervisor memberikan komentar kepada guru tentang hal-hal yang perlu ditingkatkan. Supervisi dilakukan dalam rangka menjamin pembelajaran yang berkualitas. Artinya, bahwa keberhasilan pelaksanaan supervisi diukur dari peningkatan prestasi belajar siswa. Penelitian 
Tenriningsih (2009) menemukan bahwa "terdapat hubungan langsung yang positif dan signifikan antara kinerja guru dengan prestasi belajar siswa dan terdapat hubungan langsung yang positif dan signifikan antara prestasi belajar siswa melalui supervisi pengajaran". Artinya semakin tinggi kinerja guru, semakin tinggi prestasi belajar siswa. Karena itu, untuk menghasilkan kinerja guru yang tinggi diperlukan supervisi pengajaran yang efektif yang baik dan benar.

\section{B. PERMASALAHAN}

Berdasarkan latar belakang diatas, permasalahan yang dapat disimpulkan diantaranya :

1. Apasajakah konsep dasar supervisi pendidikan?

2. Bagaimanakah proses dari supervisi pendidikan yang efektif dan benar?

3. Bagaimanakah meningkatkan kompetensi keprofesionalan dan pelaksanaan supervisi kepala sekolah beserta guru?

\section{Konsep Dasar Supervisi Pendidikan}

a) Pengertian Supervisi Pendidikan

Supervisi pendidikan adalah serangkaian kegiatan membantu guru mengembangkan kemampuannya dalam mengelola proses pembelajaran untuk mencapai tujuan pembelajaran (Daresh, 1989, Glickman, et al; 2007). Sergiovanni (1987) menegaskan bahwa refleksi praktis penilaian kinerja dosen atau instruktur dalam supervisi pendidikan adalah melihat kondisi nyata kinerja guru untuk menjawab pertanyaan-pertanyaan, misalnya apa yang sebenarnya terjadi di dalam kelas?, apa yang sebenarnya dilakukan oleh dosen atau instruktur dan siswa di dalam kelas?, dll

b) Tujuan Supervisi Pendidikan

Tujuan supervisi pendidikan adalah:

1) membantu dosen atau instruktur mengembangkan kompetensinya,

2) mengembangkan kurikulum,

3) mengembangkan kelompok kerja dosen atau instruktur, dan membimbing penelitian tindakan kelas (PTK) (Glickman, et al; 2007, Sergiovanni, 1987)

c) Prinsip Prinsip Supervisi Pendidikan

1) Praktis, artinya mudah dikerjakan sesuai kondisi Satuan Pendidikan.

2) Sistematis, artinya dikembangan sesuai perencanaan program supervisi yang matang dan tujuan pembelajaran.

3) Objektif, artinya masukan sesuai aspek-aspek instrumen.

4) Realistis, artinya berdasarkan kenyataan sebenarnya.

5) Antisipatif, artinya mampu menghadapi masalah-masalah yang mungkin 
akan terjadi.

6) Konstruktif, artinya mengembangkan kreativitas dan inovasi dosen atau instruktur dalam mengembangkan proses pembelajaran.

7) Kooperatif, artinya ada kerja sama yang baik antara supervisor dan dosen atau instruktur dalam mengembangkan pembelajaran.

8) Kekeluargaan, artinya mempertimbangkan saling asah, asih, dan asuh dalam mengembangkan pembelajaran.

9) Demokratis, artinya supervisor tidak boleh mendominasi pelaksanaan supervisi akademik.

10) Aktif, artinya dosen atau instruktur dan supervisor harus aktif berpartisipasi.

11) Humanis, artinya mampu menciptakan hubungan kemanusiaan yang harmonis, terbuka, jujur, ajeg, sabar, antusias, dan penuh humor (Dodd, 1972).

12) Berkesinambungan (supervisi akademik dilakukan secara teratur dan berkelanjutan oleh Kepala satuan pendidikan).

13) Terpadu, artinya menyatu dengan dengan program pendidikan.

14) Komprehensif, artinya memenuhi ketiga tujuan supervisi akademik di atas.

d) Dimensi Dimensi Supervisi Pendidikan

1) Kompetensi kepribadian.

2) Kompetensi pedagogik.

3) Kompotensi profesional.

4) Kompetensi sosial. (Ningrum, 2019)

\section{Proses Supervisi Pendidikan}

Proses atau Tahap tahap Pelaksanaan Supervisi Pendidikan :

a) Perencanaan

b) Pelaksanaan

c) Evaluasi

d) Menciptakan suasana kekeluargaan yang intim atara guru dengan supervisor agar komunikasi selama kegiatan dapat berlangsung secara efektif.

e) Membuat kesepakatan antara guru dengan supervisor tentang aspek proses belajar mengajar yang akan dikembangkan dan ditingkatkan, kedua perencanaan oleh guru dan supervisor yakni membuat perencanaan pelaksanaan obeservasi secara bersamaan

f) Mengenai pelaksanaan pelatihan mengajar dan observasi yang mana guru sedang melakukan proses pembelajaran sedang supervisor melakukan pengamatan secara cermat, dengan menggunakan instrument obeservasi.

g) Mengadakan analisis data, dalam hal ini supervisor mengjak guru untuk mendiskusikan apa yang telah dilaksanakan oleh guru melakukan proses pembelajaran di kelas. 
h) Langkah diskusi memberikan umpan balik yang bertujuan untuk memberikan umpan balik atas apa yang telah dilakukan oleh supervisor kepada guru yang sedang berlatih mengajar meningkatkan ketrampilannya dan pelaksanaan langkah pemberian umpan balik sebaiknya dilakukan secara objektif dan segera.

\section{Meningkatkan Kompetensi Keprofesionalan dan Pelaksanaan Supervisi Kepala Sekolah Beserta Guru}

a) Kegiatan pertama dilakukan komunikasi dan pendekatan kepada ketua KKKS atas rekomendasi kepala bidang.

b) Kegiatan kedua, dilaksanakan workshop untuk kepala sekolah dan guru. Kepala sekolah dan guru diminta untuk datang ke tempat pelaksanaan workshopsesuai dengan jadwal yang tertera pada surat undangan yang telah dikirimkan. Dalampelaksanaan kegiatan ini, dilakukan transfer ilmu,yaitu pengetahuan dan pemahaman tentang supervisi (pembinaan dan bimbingan) kepada pendidik dan tenaga kependidikan serta ilmu tentang manajemen sekolah yang mencakup 8 standar pendidikan.

\begin{tabular}{|c|c|c|}
\hline No & Nama & Narasumber \\
\hline 1 & $\begin{array}{l}\text { Manajemen sekolah di era } 4.0 \text { dan } \\
\text { diskusi }\end{array}$ & Drs. Syahril, P.hD. \\
\hline 2 & 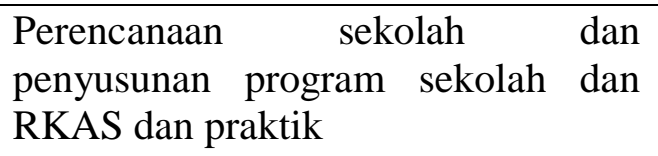 & Dr. Hadiyanto, M.Ed \\
\hline 3 & $\begin{array}{l}\text { Pemanfaatan informasi dan teknologi } \\
\text { bagi peningkatan pembelajaran dan } \\
\text { manajemen sekolah dan praktik }\end{array}$ & $\begin{array}{l}\text { Tia Ayu Ningrum, } \\
\text { M.Pd. }\end{array}$ \\
\hline 4 & $\begin{array}{l}\text { Manajemen peserta } \\
\text { konseling didik diskusi }\end{array}$ & $\begin{array}{l}\text { Prof. Dr. Nevi, M.Pd. } \\
\text { Kons. }\end{array}$ \\
\hline
\end{tabular}

c) Kegiatan ketiga, dilakukan bimbingan tekink untuk membuat rencana atau program supervisi dan instrumen supervisi.

d) Pada tahap evaluasi, dilakukan evaluasi kegiatan dan juga penyelesaian administrasi dan laporan. Laporan yang ditulis adalah laporan hasil kegiatan dan pengumpulan laporan hasil kegiatan. Kemudian juga membuat laporan keuangan kegiatan dan luaran dari kegiatan. (Ningrum, 2019) 


\section{PEMECAHAN MASALAH}

Kerangka pemecahan masalah yang dilakukan untuk mengatasi permasalahan kompetensi manajerial dan supervisi kepala sekolah dan guru, yaitu dengan melakukan transfer pengetahuan, dan keterampilan yang dilakukan melalui workshop dan bimbingan teknik. Workshop dan bimtek tentang kompetensi manajerial dan supervisi kepala sekolah meliputi dua aspek, yaitu aspek kompetensi manejerial dan kompetensi supervisi. Pada aspek kompetensi manajemerial, solusi yang diberikan dalam menyelesaikan permasalahan tersebut adalah dengan melakukan transfer ilmu tentang manajemen sekolah. (Ningrum, 2019)

Sedangkan Supervisi akademik adalah serangkaian kegiatan membantu guru mengembangkan kemampuannya dalam mengelola proses pembelajaran untuk mencapai tujuan pembelajaran. Teknik-teknik supervisi akademik ada dua, yaitu teknik individual dan teknik kelompok. supervisi klinis bagi dosen atau instruktur muncul ketika dosen atau instruktur tidak harus disupervisi atas keinginan kepala Satuan Pendidikan sebagai supervisor tetapi atas kesadaran dosen atau instruktur untuk datang ke supervisor untuk minta bantuan mengatasi masalahnya.

\section{E. DAFTAR PUSTAKA}

Ningrum, tia ayu. (2019). PEMBINAAN KOMPETENSI MANAJERIAL DAN SUPERVISI KEPALA SEKOLAH. Jurnal Halqalah, 3(1), 429 - 432.

Ningrum, tia ayu. (2019). PERSEPSI PEGAWAI TENTANG PELAKSANAAN PENGAWASAN YANG DILAKUKAN PIMPINAN DINAS PENDIDIKAN DAN KEBUDAYAAN KABUPATEN TANAH DATAR. Jurnal Bahana Manajemen Pendidikan. 2(1), 337-342.

Prasojo, Lantip Diat. (2019). SUPERVISI PENDIDIKAN. http://staff.uny.ac.id/sites/default/files/tmp/Makalah\%20Supervisi\%20perhutani.pdf. 2(3), 2-34 
